\title{
ANÁLISE JURÍDICA DO LOTEAMENTO DE ACESSO CONTROLADO E DO CONDOMÍNIO DE LOTES NA LEI FEDERAL № 13.465/2017
}

\section{LEGAL ANALYSIS OF THE CONTROLLED ACCESS ALLOTMENTS AND THE CONDOMINIUM OF LOTS IN THE FEDERAL LAW NO. 13.465/2017}

\section{Vinícius Monte Custodio ${ }^{1}$}

\begin{abstract}
Resumo
A Medida Provisória no 759, de 22 de dezembro de 2016, promoveu uma reviravolta na legislação urbanística federal do Brasil, sendo sancionada como a Lei Federal no 13.465, de 11 de julho de 2017. Entre diversas inovações, essa lei introduziu as figuras jurídicas do loteamento de acesso controlado e do condomínio de lotes. Este trabalho investiga o sentido e o alcance dessas duas figuras, e as mudanças por elas engendradas, partindo da premissa de que 0 processo legislativo e as discussões foram açodadas pelo rito da medida provisória. E conclui, quanto ao loteamento de acesso controlado, que ele é inconstitucional por violação do princípio da igualdade, dos direitos à intimidade e à vida privada e da liberdade de associação. Já quanto ao condomínio de lotes, conclui que ele apresenta um problema teleológico, pois não resolve o quadro de insegurança jurídica a que visa superar; e um problema conceitual, pois, ao não definir expressamente a natureza jurídica dos terrenos onde são constituídos os condomínios de lotes, a lei não deixa claro se suas partes comuns têm destinação à edificação ou não.
\end{abstract}

Palavras-Chave: Parcelamento do solo urbano, Loteamento de acesso controlado, Condomínio de lotes.

\begin{abstract}
The Provisional Measure no. 759, $22^{\text {nd }}$ of December 2016, overhauled Brazil's federal planning legislation. During its passage through National Congress, being sanctioned as Federal Law no. $13.465,11^{\text {th }}$ of July 2017 . Amongst its numerous innovations, this law has introduced the legal entities of the controlled access allotment and the condominium of lots. This paper examines the meaning and the reach of the two aforementioned legal entities and the changes occasioned by them, starting from the premise that the legislative procedure and discussions were hastened by the provisional measure rite. And it concludes, as far as it concerns the controlled access allotment, that it is unconstitutional due to the violation of the principle of equality, of the rights to intimacy and private life, and the liberty of association. As far as it concerns the condominium of lots, it concludes that it poses a teleological problem, insofar as it does not address the legal uncertainty framework it purports to overcome; and a conceptual problem, because, as long as it does not explicitly define the legal nature of the lands where the condominium of lots are constituted, the law does not make it clear whether their common parts are aimed to building or not.
\end{abstract}

Keywords: Urban land subdivision, Controlled access allotment, Condominium of lots.

\footnotetext{
${ }^{1}$ Mestre em Ciências Jurídico-Políticas com menção em Direito do Ordenamento, do Urbanismo e do Ambiente pela Universidade de Coimbra. E-mail: montecustodio@gmail.com
} 


\section{INTRODUÇÃO}

A Lei do Parcelamento do Solo Urbano (Lei Federal no 6.766, de 19 de dezembro de 1979), também conhecida como Lei Lehmann, em homenagem ao senador autor do projeto, consagrou expressamente duas modalidades de parcelamento do solo urbano: o loteamento e o desmembramento. ${ }^{2}$ De um lado, loteamento é "a subdivisão de gleba em lotes destinados a edificação, com abertura de novas vias de circulação, de logradouros públicos ou prolongamento, modificação ou ampliação das vias existentes" (art. 2ํ, § 1ํ). Do outro, desmembramento é "a subdivisão de gleba em lotes destinados a edificação, com aproveitamento do sistema viário existente, desde que não implique na abertura de novas vias e logradouros públicos, nem no prolongamento, modificação ou ampliação dos já existentes" (art. $\left.2^{\circ}, \S 2 \stackrel{\circ}{\circ}\right)$.

Outras duas figuras jurídicas correlatas, a despeito da ausência de previsão legal expressa, são apontadas pela doutrina e jurisprudência no Brasil: o loteamento fechado e o condomínio urbanístico. ${ }^{3}$ O loteamento fechado é uma situação jurídica em que as vias de circulação abertas, prolongadas, modificadas ou ampliadas para a implantação do loteamento, bens que integram o domínio municipal desde a data de seu registro (art. 22, caput, da Lei Federal no 6.766/1979), estão cerradas ou embaraçadas ao uso comum do povo, mediante a instalação de portões, grades ou cancelas, às vezes acompanhados de guaritas ou portarias, com ou sem a anuência do Poder Público local, visando à segurança e ao conforto dos habitantes dos lotes derivados da gleba original. ${ }^{4} \mathrm{E}$ o condomínio urbanístico, que é a subdivisão da gleba, não em lotes destinados à edificação, mas em unidades autônomas, a que correspondem frações ideais inseparáveis do terreno e das partes comuns, com arruamento privado (vias internas) e sem destinação de áreas para implantação de equipamentos públicos e espaços livres de uso público.

Em 22 de dezembro de 2016, o Presidente da República adotou a Medida Provisória (MP) no 759, que dispõe sobre a regularização fundiária rural e urbana, a liquidação de créditos concedidos aos assentados da reforma agrária e a regularização fundiária no âmbito da Amazônia Legal, bem assim institui mecanismos para aprimorar a eficiência dos procedimentos

\footnotetext{
2 "Art. 2o. O parcelamento do solo urbano poderá ser feito mediante loteamento ou desmembramento, observadas as disposições desta Lei e as das legislações estaduais e municipais pertinentes."

${ }^{3}$ Cf., por todos, MEIRELLES, H. L. Direito municipal brasileiro, 17. ed. atualizada por Adilson Abreu Dallari (coord.). São Paulo: Malheiros, 2014, p. 585-586.

${ }^{4}$ No entanto, os loteamentos fechados sem a anuência do município configuram um verdadeiro crime de esbulho possessório de bens públicos (art. 161, inc. II, do Código Penal).
} 
de alienação de imóveis da União e dá outras providências, promovendo uma reviravolta na legislação urbanística federal. Editada manifestamente sem preencher o requisito de urgência contido no art. 62, caput, da Constituição da República (CRFB), a MP no 759/2016 recebeu 732 (setecentos e trinta e duas) propostas de emenda parlamentar durante sua tramitação no Congresso Nacional. Em seguida, a Comissão Mista analisou o projeto e as emendas apresentadas, aprovando o Parecer (CN) № 1, de 03 de maio de 2017, sob a relatoria do Sen. Romero Jucá, que concluiu pelo Projeto de Lei de Conversão no 12/2017, posteriormente sancionado como a Lei Federal no 13.465, de 11 de julho de 2017. Entre as numerosas novidades trazidas por essa lei, avultam-se as figuras jurídicas do loteamento de acesso controlado (art. 78) e do condomínio de lotes (art. 58 e 78), que são o tema deste trabalho.

O problema a ser respondido é se a Lei Federal no 13.465/2017, com a consagração do loteamento de acesso controlado e do condomínio de lotes, finalmente resolveu a insegurança jurídica e os vícios de inconstitucionalidade suscitados pelos loteamentos fechados e pelos condomínios urbanísticos. Portanto, o objetivo do artigo é analisar o sentido e o alcance do loteamento de acesso controlado e do condomínio de lotes, bem assim as mudanças operadas em nosso ordenamento pátrio a partir de sua vigência, comparando essas duas figuras com seus antecedentes jurídicos. A justificativa deste trabalho foi o açodamento do processo legislativo e das discussões das matérias em pauta com a academia, comunidade jurídica e sociedade civil, de uma maneira geral, ocasionado pela medida provisória.

Nossas hipóteses são de que o loteamento de acesso controlado, conquanto mitigue os vícios de inconstitucionalidade do loteamento fechado, ainda assim atenta contra a Constituição da República; e de que o condomínio de lotes, não obstante seja constitucionalmente válido, apresenta problemas de ordem teleológica e de ordem conceitual, carecendo de reparos do legislador.

Em razão da considerável proximidade temporal, nosso marco teórico limitar-se-á à doutrina e jurisprudência brasileiras sobre parcelamento do solo urbano, especialmente a figura do loteamento fechado, e condomínio edilício pré-existentes à Lei Federal no 13.465/2017. Portanto, ante a escassez de fontes teóricas com o rigor científico pretendido neste estudo, quer na academia quer nos tribunais, o que é plenamente justificado pela novidade do tema, optar-se-á pela construção de uma teoria original, através de ângulos ainda inexplorados.

Por último, cabe informar que, no dia 31 de agosto de 2017, a Procuradoria-Geral da República ajuizou ação direta de inconstitucionalidade (ADI no 5.771), distribuída por sorteio à relatoria do Min. Luiz Fux, pedindo o deferimento de medida cautelar para suspender a eficácia 
total da Lei Federal no 13.465/2017 e, ao final do processo, a declaração de inconstitucionalidade integral dessa lei. Porém, verdade seja dita, nenhuma menção foi especificamente feita ao loteamento de acesso controlado ou ao condomínio de lotes.

\section{LOTEAMENTO DE ACESSO CONTROLADO}

Até à entrada em vigor da Lei Federal no 13.465/2017, a Lei do Parcelamento do Solo Urbano era omissa quanto à possibilidade de o município autorizar o fechamento de loteamentos, mas alguma doutrina já sustentava tal possibilidade com amparo na concessão de direito real de uso de terrenos públicos, positivada pelo art. 7으, caput, do Decreto-Lei no 271, de 28 de fevereiro de 1967, a antiga Lei de Loteamentos Urbanos. ${ }^{5-6}$ Como a Lei Lehmann não revogou expressamente esse dispositivo, para essa corrente dogmática, o município poderia proceder à desafetação do uso comum dos logradouros públicos em questão e, em seguida, afetá-los ao uso especial dos habitantes do loteamento por meio da concessão de direito real de uso. $^{7-8}$ Essa tese, contudo, carrega consigo uma série de dificuldades de ordem constitucional.

\footnotetext{
${ }^{5}$ Cf., por todos, KOJRANSKI, N. Condomínio edilício: aspectos jurídicos relevantes, 2. ed. São Paulo: Malheiros, 2015, p. 325-326; 340-346.

6 "Art. 7 O É instituída a concessão de uso de terrenos públicos ou particulares, remunerada ou gratuita, por tempo certo ou indeterminado, como direito real resolúvel, para fins específicos de regularização fundiária de interesse social, urbanização, industrialização, edificação, cultivo da terra, aproveitamento sustentável das várzeas, preservação das comunidades tradicionais e seus meios de subsistência ou outras modalidades de interesse social em áreas urbanas", na redação dada pela Lei Federal no 11.481, de 31 de maio de 2007.

7 LOPES MEIRELLES, com base em sua interpretação do art. 67 do Código Civil de 1916 (correspondente ao art. 100 do atual Código Civil), conclui que a desafetação de bens de uso comum do povo depende de autorização legal, cf. Direito administrativo brasileiro, 16. ed. atualizada pela Constituição de 1988. São Paulo: RT, 1991, p. 437. Sem embargo, na opinião de CARVALHO FILHO, trata-se de um fato administrativo, portanto sendo irrelevante a forma pela qual se processa a alteração da finalidade da coisa: se por ato administrativo ou por fato jurídico de natureza diversa, cf. Manual de Direito Administrativo. Rio de Janeiro: Lumen Juris, 2007, p. 994. Já TOSHIO MUKAI pensa que, enquanto para a desafetação de bens de uso especial basta a aprovação de lei, para a desdestinação de bens de uso comum do povo, além da anuência legal, é necessário que os bens não estejam, no plano fático, quer por desuso, quer por abandono, afetos a sua finalidade pública originária, cf. Impossibilidade jurídica da desafetação legal de bens de uso comum do povo, na ausência de desafetação de fato. In.: Revista de Direito Público, n. 75. São Paulo: RT, 1985, p. 246-249. Para nós, discordando das três posições acima, a desafetação não é um fato administrativo nem, tampouco, o art. 100 do Código Civil exige autorização legal para a alteração da finalidade de bens públicos. Por se tratar de um ato jurídico de efeitos individuais e concretos, ainda que procedida por meio de lei, a desafetação é um ato materialmente administrativo, pelo que reputamos lícita sua formalização via decreto do Poder Executivo, desde que o bem não haja sido originalmente afetado mediante lei ou que a respectiva lei orgânica municipal imponha a autorização legislativa.
} 
Sendo a concessão de direito real de uso uma modalidade de contrato administrativo, celebrado entre a Administração Pública e terceiros, por instrumento público ou particular, ou por simples termo administrativo (art. 7으, $\S 1$ 으, do Decreto-Lei no 271/1967), o primeiro passo, para a delimitação subjetiva dos concessionários, é exigir dos habitantes do loteamento que eles se organizem formalmente em associação de moradores, registrando seus atos constitutivos no Registro Civil das Pessoas Jurídicas. ${ }^{9}$ Dois problemas daí exsurgem: (I) na relação interna do loteamento fechado, a cobrança de contribuição compulsória dos moradores do loteamento para a manutenção dos serviços prestados pela associação; e, (II) na relação externa do loteamento fechado, a afetação desses logradouros públicos ao uso especial dos moradores em detrimento do uso comum do povo.

Quanto à relação interna do loteamento fechado, o art. 7으, § 2으, do Decreto-Lei no 271/1967 estatui que "[d]esde a inscrição da concessão de uso, o concessionário fruirá plenamente do terreno para os fins estabelecidos no contrato e responderá por todos os encargos civis, administrativos e tributários que venham a incidir sobre o imóvel e suas rendas". Significa dizer que, na prática, ao conceder o direito real de uso sobre as vias de circulação e demais áreas doadas para o uso público como condição para a aprovação do projeto de loteamento, o município desincumbe-se da manutenção desses imóveis públicos e de seu mobiliário urbano, bem como da prestação de serviços públicos neles (v.g., coleta domiciliar de lixo, jardinagem, varrição de ruas, iluminação pública, recapeamento de asfalto etc.), repassando os respectivos custos às associações de moradores. Para custear suas atividades em geral e fazer frente a tais despesas em particular, as associações de moradores estabelecem formas de contribuição associativa, geralmente impondo a cobrança de uma mensalidade ou anualidade a seus associados. ${ }^{10}$

Muitas associações, que conceitualmente se constituem "pela união de pessoas" (in casu, de moradores) organizadas "para fins não econômicos", nos termos do art. 53 do Código Civil (Lei Federal no 10.406, de 10 de janeiro de 2002), respaldadas por disposições estatutárias prevendo a adesão automática de adquirentes de imóveis localizados dentro do loteamento, ou

\footnotetext{
8 Mutatis mutandi, essa construção jurídica não exclui a possibilidade de outras formas jurídicas de outorga de próprios municipais à utilização privada, como a autorização de uso e a concessão de uso, ambas de natureza obrigacional (pessoal).

${ }^{9}$ Código Civil: "Art. 45. Começa a existência legal das pessoas jurídicas de direito privado com a inscrição do ato constitutivo no respectivo registro, precedida, quando necessário, de autorização ou aprovação do Poder Executivo, averbando-se no registro todas as alterações por que passar o ato constitutivo."

${ }^{10}$ Aliás, o próprio art. 54, inc. IV, do Código Civil prescreve que o estatuto das associações conterá, sob pena de nulidade, "as fontes de recurso para sua manutenção".
} 
de restrições urbanísticas convencionais do loteamento supletivas da legislação pertinente (art. 26, inc. VII, da Lei Federal no 6.766/1979), pugnam pela contribuição obrigatória de todos os moradores do loteamento, como se se tratasse de uma obrigação propter rem no âmbito de uma relação condominial. Nas palavras de NELSON KOJRANSKI, "a gestão administrativa do loteamento reclama a organização de um comando, que se apresente perante os moradores com alguma boa dose de legitimidade. Na falta de previsão legal, inventou-se a figura fictícia de associações de amigos, com o objetivo declarado de responder pela administração do loteamento. Imitou-se, para tanto, a estrutura legal dos condomínios edilícios. A convenção condominial foi substituída pelos estatutos sociais, onde vêm regulamentadas as funções do síndico, do conselho consultivo e, evidentemente, da assembleia-geral, órgão soberano do loteamento" - grifos do original. E encerra: "[t]oda essa estrutura administrativa foi arquitetada com o fim de compelir os moradores a contribuir com as taxas da administração ou de conservação, a exemplo do que ocorre as despesas de condomínio." ${ }^{11}$ Inclusive existe farta jurisprudência denominando - impropriamente - tais relações jurídicas como condomínios de fato, condomínios irregulares, condomínios fechados, condomínios por adesão, condomínios assemelhados, condomínios horizontais, condomínios urbanísticos etc. ${ }^{12}$

Os loteamentos fechados representam uma situação jurídica explicável, em parte, pela realidade de insegurança que grassa nos centros urbanos do país e, em parte, pela insuficiência, precariedade e má qualidade da manutenção de bens públicos e da prestação de serviços públicos, custeados pela arrecadação tributária, designadamente de impostos. O principal argumento para fundamentar a legitimidade da contribuição associativa compulsória é o princípio da vedação do enriquecimento sem causa (art. 884, caput, do Código Civil), corolário do postulado de justiça (art. 3ㅇ, inc. I, da CRFB) e do princípio da igualdade (art. 5으, caput, da (RFB). ${ }^{13}$

Essa vinha sendo a posição dominante nos tribunais brasileiros, tanto que o Tribunal de Justiça do Estado do Rio de Janeiro - TJRJ aprovou a Súmula no 79 em abril de 2005, nos termos da qual "[e]m respeito ao princípio que veda o enriquecimento sem causa, as associações de moradores podem exigir dos não associados, em igualdade de condições com os associados,

\footnotetext{
${ }^{11}$ Condomínio edilício: aspectos jurídicos relevantes, 2. ed. São Paulo: Malheiros, 2015, p. 362.

12 Em setembro de 2002, o Conselho da Justiça Federal (CJF) até editou, na I Jornada de Direito Civil, o Enunciado no 89, segundo o qual "[o] disposto nos arts. 1.331 a 1.358 do novo Código Civil aplica-se, no que couber, aos condomínios assemelhados, tais como loteamentos fechados, multipropriedade imobiliária e clubes de campo" - grifos nossos.

13 "Art. 884. Aquele que, sem justa causa, se enriquecer à custa de outrem, será obrigado a restituir o indevidamente auferido, feita a atualização dos valores monetários."
} 
que concorram para o custeio dos serviços por elas efetivamente prestados e que sejam do interesse comum dos moradores da localidade" - grifos nossos. ${ }^{14}$

Porém, ainda naquele ano, a Segunda Seção do Superior Tribunal de Justiça - STJ começou a reverter a jurisprudência até então dominante, nos Embargos de Divergência no Recurso Especial (EREsp) no 444.931/SP. ${ }^{15}$ Abrindo a divergência do relator, o Min. Menezes Direito esclareceu que, no acórdão embargado, votou no sentido da impossibilidade de cobrança de contribuição associativa, porque "a parte recorrente adquiriu o seu lote em loteamento aberto, sem a existência de qualquer associação", acompanhando o entendimento esposado pelo Min. Ari Pargendler, que engrossou a divergência aberta. O Min. Humberto Gomes de Barros completou a maioria, reafirmando a posição preexistente do proprietário face à associação, bem assim sua recusa em se associar. E encerrou da seguinte forma: "[e]m nosso ordenamento jurídico há somente três fontes de obrigações: a lei, o contrato ou o débito. No caso, não atuam qualquer dessas fontes."

Em setembro de 2011, foi a Primeira Turma do STF, no Recurso Extraordinário (RE) no 432.106/RJ, protocolado antes da entrada em vigor do instituto da repercussão geral, quem deu um passo adiante. ${ }^{16}$ Por unanimidade, os ministros acolheram o voto do Rel. Min. Marco Aurélio, que lembrou que "ninguém será obrigado a fazer ou deixar de fazer alguma coisa senão em virtude de lei" (art. 5ำ, inc. II, da CRFB). Nessa medida, sem manifestação de vontade, ou previsão em lei, é incabível a cobrança de mensalidade ou contribuição associativa, já que "ninguém poderá ser compelido a associar-se ou a permanecer associado" (art. 50, inc. XX). Para o relator, a aplicação da vedação do enriquecimento sem causa levaria a um esvaziamento da liberdade de associação, que "alcança não só a associação sob o ângulo formal como também tudo que resulte desse fenômeno e, iniludivelmente, a satisfação de mensalidades ou de outra parcela, seja qual for a periodicidade, à associação pressupõe a vontade livre e espontânea do cidadão em associar-se." ${ }^{17}$

\footnotetext{
${ }^{14}$ FEDOZZI, M. E. G. Condomínio edilício no Novo Código Civil. Rio de Janeiro: Forense, 2007, p. 132.

${ }^{15}$ EREsp no 444.931/SP (Segunda Seção). In: Diário da Justiça, 01 fev. 2006. Rel Min. Fernando Gonçalves.

${ }^{16}$ RE no 432.106/RJ (Primeira Turma). In: Diário da Justiça Eletrônico, 04 nov. 2011. Rel. Min. Marco Aurélio.

${ }^{17}$ Precisamente um mês depois desse aresto, no Agravo de Instrumento no 745.831/SP ${ }^{17}$, convertido no Recurso Extraordinário no 695.911/SP, a maioria do STF reconheceu a repercussão geral (Tema de Repercussão Geral no 492) de caso similar ao que vimos de expor, nos termos do voto do Rel. Min. Dias Toffoli, que considerou que a "efetiva aplicação do princípio da liberdade de associação", nomeadamente em associações de moradores, com "a consequente sujeição à cobrança de taxas em loteamentos imobiliários, é de índole eminentemente constitucional, pois diz respeito à correta aplicação, em tais casos, do princípio da legalidade", assim como "extrapola os interesses subjetivos das partes". O recurso
} 
Por fim, em março de 2015, a Segunda Seção do STJ, julgando o REsp no 1.280.871/SP'18, no rito dos recursos repetitivos, firmou a tese de que "as taxas de manutenção criadas por associações de moradores não obrigam os não associados ou que a eles não anuíram." Inicialmente, o Rel. Min. Bôas Cueva, na senda da posição firmada pela Corte no EREsp no 444.931/SP, consignou que "o critério a ser utilizado para determinar se o proprietário de imóvel integrante de loteamento fechado deve obrigatoriamente responder pelas despesas coletivas é o momento em que o imóvel foi adquirido em relação à constituição da associação de moradores" - grifos do original. Assim, em sua ótica, quando a associação de moradores for preexistente à aquisição do imóvel pelo morador que a ela não queira aderir, a cobrança será devida; já quando a relação de propriedade for anterior à constituição da associação, o morador eximir-se-á de contribuir para o custeio de tais despesas. Todavia, prevaleceu o entendimento do Min. Marco Buzzi, de acordo com o qual, "se a compra se opera em data posterior à constituição da associação, na ausência de fonte criadora da obrigação (lei ou contrato), é defeso ao poder jurisdicional, apenas calcado no princípio enriquecimento sem causa, em detrimento aos princípios constitucionais da legalidade e da liberdade associativa, instituir um dever tácito a terceiros" - grifos do original. Não obstante, conforme advertiu - com inteira justiça, diga-se - a Min. Maria Isabel Gallotti em seu voto, que acompanhou a divergência iniciada pelo Min. Marco Buzzi, "o acolhimento desta tese não significa que não possa, em tese, haver o ajuizamento de ação de indenização por enriquecimento sem causa quando alegado e demonstrado que o morador se beneficia, utiliza concretamente de serviços fornecidos pela associação e por eles nada paga."

Quanto à relação externa do loteamento fechado, a afetação desses logradouros públicos ao uso especial dos moradores em detrimento do uso comum do povo encontraria amparo constitucional no direito ao bem-estar dos habitantes da cidade (art. 182, caput), objetivo da política de desenvolvimento urbano e, em última análise, consequência do direito à segurança (art. 50, caput) e do direito à sadia qualidade de vida (art. 225, caput). ${ }^{19}$ No entanto, essa inteligência fica prejudicada quando confrontada com argumentos outros, de igual envergadura constitucional. Em primeiro lugar, loteamentos fechados agridem o princípio da

ainda aguarda julgamento, cf. Al no 745.831-RG/SP. In: Diário da Justiça Eletrônico, 29 nov. 2011. Rel. Min. Dias Toffoli.

18 REsp no 1.280.871/SP (Segunda Seção). In: Diário da Justiça Eletrônico, 22 maio 2015. Rel Min. Ricardo Villas Bôas Cueva.

${ }^{19}$ KOJRANSKI, N. Condomínio edilício: aspectos jurídicos relevantes, 2. ed. São Paulo: Malheiros, 2015, p. 315-379. 
igualdade (art. 5o, caput), porque favorecem determinados habitantes da cidade, em detrimento do resto da coletividade, com um uso especial de bens públicos de uso comum do povo (v.g., ruas, praças, jardins, gramados, lagos artificiais etc.) sem uma justificativa plausível. Em segundo lugar, o controle de acesso a loteamento, por meio de guaritas ou portarias, ofende os direitos à intimidade e à vida privada (art. 5으, inc. X) daqueles que são constrangidos, sem razão legal, a se identificarem perante terceiros para adentrarem os respectivos logradouros públicos. Em terceiro lugar, a instalação de portões, grades ou cancelas para fechamento de loteamentos ataca a liberdade de locomoção no território nacional em tempo de paz (art. 5ㅇ, inc. XV), vulgarmente conhecida como o "direito de ir e vir". Em quarto lugar, como desdobramento desta última, o fechamento de vias públicas também põe em causa o direito à mobilidade urbana eficiente (art. 144, § 10, inc. I), pois desconecta e desarticula a malha viária da cidade, dificultando a boa circulação de pessoas e veículos. E em último lugar, loteamentos fechados são inconciliáveis com, pelo menos, três das quatro funções sociais da cidade (art. 182, caput) concebidas por LE CORBUSIER na Carta de Atenas, que sintetizou e interpretou as conclusões do IV Congresso Internacional de Arquitetura Moderna (1933), quais sejam trabalhar, recrear-se (nas horas livres) e circular. ${ }^{20-21}$

Seja como for, o fato é que o STF ainda não foi chamado a decidir a celeuma dos loteamentos fechados sob o ângulo da relação externa. É dizer, a jurisprudência do Pretório Excelso, até ao presente momento, tão somente se limitou a julgar a questão com base na relação interna dos moradores de loteamentos fechados. Portanto, falta ao Tribunal Constitucional perquirir a constitucionalidade propriamente dita dos loteamentos fechados, o que inexoravelmente conduzirá a uma análise de mérito na perspectiva da relação externa desses empreendimentos com os habitantes do restante da cidade. Essa não é a causa de pedir do RE no 695.911/SP, que se centra na relação interna dos loteamentos fechados, nem foi a do RE no 607.940/DF, que focou na discussão sobre se o plano diretor deve exaurir a normativa urbanística municipal ou não. Mesmo assim, este último aresto é particularmente interessante, por sinalizar uma possível orientação de nossa Suprema Corte no âmbito da relação externa dos

\footnotetext{
${ }^{20}$ LE CORBUSIER. A Carta de Atenas, trad. Rebeca Scherer. São Paulo: HUCITEC: EDUSP, 1993, tópico no 77.

${ }^{21}$ A propósito, no RE no 607.940/DF, o voto da Min. Cármen Lúcia esclareceu que as "funções sociais da cidade", contidas no art. 182, caput, da Constituição da República, são "trabalhar, habitar, circular e ter atividades de lazer", com isso reconhecendo os princípios do urbanismo moderno preconizados por Le Corbusier.
} 
loteamentos fechados. O Min. Dias Toffoli, corroborando os argumentos do MPDFT, afirmou em seu voto que:

A implantação de loteamentos fechados afeta o planejamento urbanístico global e repercute no direito de locomoção, no direito ao uso e à ocupação do solo, no meio ambiente, na arrecadação tributária do município, na segurança pública", bem assim "tem profunda implicação para a adequada distribuição espacial das atividades socioeconômicas e dos equipamentos urbanos e comunitários, para a justa distribuição dos benefícios e ônus decorrentes do processo de urbanização e para a prevalência do interesse coletivo sobre o individual e do interesse público sobre o privado.

E, complementou:

Embora lei distinta do plano diretor possa vir a regular o ordenamento urbano, esse deverá sempre guardar obediência não apenas para com aquele diploma normativo, mas também para com as garantias constitucionais dos demais cidadãos, aqueles que residem fora dos muros do loteamento fechado." Por último, declarou que "qualquer regra que venha a inviabilizar o exercício das liberdades e garantias fundamentais dos demais indivíduos há de ser prontamente rechaçada, ainda que sob o aspecto formal possa parecer hígida.

Apesar disso, do ponto de vista formal, o Min. Dias Toffoli considerou constitucional a lei complementar distrital, porque ela não ofenderia o art. 182, $\S \S 1$ e 2 , da CRFB, norma adotada como paradigma pelo MPDFT para questionar a constitucionalidade da LCD $\mathrm{n}$ 은 $710 / 2005$.

Agora, com a Lei Federal ํo 13.465/2017, incluiu-se um § 8ㅇ no art. 2으 da Lei Federal no 6.766/1979, que instituiu o loteamento de acesso controlado como "a modalidade de loteamento [...] cujo controle de acesso será regulamentado por ato do Poder Público municipal, sendo vedado o impedimento de acesso a pedestres ou a condutores de veículos, não residentes, devidamente identificados ou cadastrados." Várias conclusões de ordem lógica podem ser extraídas dessa inovação jurídica.

A primeira conclusão é que a definição legal de loteamento de acesso controlado não como uma situação jurídica, mas como uma modalidade de loteamento, implica na necessidade de anuência da Prefeitura Municipal, sem a qual aquele será considerado um loteamento fechado, que - além de inconstitucional - doravante passa a ser uma situação estritamente ilegal. A segunda conclusão é que sem a densificação em nível municipal do controle de acesso, ou seja, sem lei ou regulamento municipal que disponha, por exemplo, sobre os tipos de construção admitidos para a restrição do fluxo de pessoas e veículos (v.g., portões, grades, cancelas, guaritas, portarias etc.), os modos de sinalização (v.g., placas, faixas e luzes) e seus dizeres obrigatórios (v.g., "logradouro público", "bem de uso comum do povo" etc.), as formas e 
condições de identificação ou cadastro de transeuntes (v.g., proibição de coleta de informações relativas a orientação sexual, religiosa ou política, vedação de justificação ou exposição de motivos para o acesso etc.), o controle de acesso não pode ser feito. A terceira conclusão é que o legislador brasileiro, ao tornar defeso o impedimento de acesso a pedestres ou a condutores de veículos, não residentes, devidamente identificados ou cadastrados, automaticamente jogou para a ilegalidade toda lei ou regulamento municipal que admite ou vier a admitir o cerceamento da liberdade de locomoção no arruamento interno de loteamentos após a identificação ou cadastro do indivíduo. A quarta conclusão é que a expressão "não residentes" cumpre uma função meramente enfática, qual seja explicitar que não só residentes, mas qualquer um do povo, desde que devidamente identificado ou cadastrado, tem direito de acesso ao arruamento interno de loteamentos, evitando com isso interpretações jurídicas hostis ao "direito de ir e vir". E a quinta conclusão é que, conquanto vede o impedimento de acesso a não residentes, pedestres ou condutores de veículos, o art. 2o, $\S$ 8o, da Lei Federal no 6.766/1979 condiciona tal acesso a identificação ou cadastro. Por essa razão, está inquinado de inconstitucionalidade por ofensa ao princípio da igualdade (art. 5ㅇ, caput) e aos direitos à intimidade e à vida privada (art. 5o, inc. X), na medida em que constrange não residentes do loteamento - e só esses - a se identificarem perante terceiros para adentrarem os respectivos logradouros públicos.

A nova lei ainda incluiu um confuso art. 36-A na Lei de Parcelamento do Solo Urbano, cujo caput, em síntese, assemelha a atividade das associações de moradores à atividade de administração de imóveis, e cujo parágrafo único parece validar a cobrança compulsória de cota associativa na forma de seus atos constitutivos. ${ }^{22}$ Malgrado a criação da obrigação legal de cotização para a administração imobiliária empreendida pelas associações de moradores e entidades afins enfraqueça o argumento do princípio da legalidade (art. 5o, inc. II, da CRFB), o art. 36-A não logrou superar o argumento da liberdade de associação (art. 5o, inc. XX), razão pela qual há igualmente de ser tido por inconstitucional.

\footnotetext{
22 "Art. 36-A. As atividades desenvolvidas pelas associações de proprietários de imóveis, titulares de direitos ou moradores em loteamentos ou empreendimentos assemelhados, desde que não tenham fins lucrativos, bem como pelas entidades civis organizadas em função da solidariedade de interesses coletivos desse público com o objetivo de administração, conservação, manutenção, disciplina de utilização e convivência, visando à valorização dos imóveis que compõem o empreendimento, tendo em vista a sua natureza jurídica, vinculam-se, por critérios de afinidade, similitude e conexão, à atividade de administração de imóveis. (Incluído pela Lei no 13.465, de 2017)

"Parágrafo único. A administração de imóveis na forma do caput deste artigo sujeita seus titulares à normatização e à disciplina constantes de seus atos constitutivos, cotizando-se na forma desses atos para suportar a consecução dos seus objetivos. (Incluído pela Lei no 13.465, de 2017)"
} 


\section{CONDOMÍNIO DE LOTES}

A Lei de Condomínios em Edificações e Incorporações Imobiliárias (Lei Federal no 4.591, de 16 de dezembro de 1964), também conhecida como Lei Caio Mário, em homenagem ao autor do anteprojeto, enquadrou o condomínio edilício (também conhecido como propriedade horizontal) como edificações ou conjuntos de edificações, de um ou mais pavimentos, constituídos por unidades autônomas, cada uma correspondendo a uma fração ideal inseparável do terreno e das partes comuns, expressa de forma decimal ou ordinária no ato constitutivo, destinadas a fins residenciais ou não residenciais, com acesso direto ou por passagem comum (v.g., escada, corredor, rampa ou elevador) ao logradouro público. ${ }^{23}$

O condomínio em conjuntos de edificações, previsto no art. 8o da Lei Federal no 4.591/1964, é um caso especial de condomínio edilício em que as unidades autônomas são constituídas em casas térreas ou assobradadas (alínea 'a') ou constituem edifícios de dois ou mais pavimentos (alínea 'b'). Difere da propriedade horizontal tradicional, pois aqui é necessário discriminar a parte do terreno ocupada pela edificação e aquelas que eventualmente forem reservadas à utilização exclusiva das unidades autônomas. Além disso, devem ser discriminadas as partes do total do terreno que poderão ser utilizadas em comum pelos titulares de direito sobre os vários tipos de unidades autônomas (alínea ' $c$ ') e as áreas que se constituírem em passagem comum paras as vias públicas ou para as unidades entre si (alínea ' $d$ '). ${ }^{24-25}$

\footnotetext{
${ }^{23}$ Com efeito, a terminologia "condomínio edilício" só surge com o Código Civil de 2002 (arts. 1.331 a 1.358), que transplantou sem mudanças substanciais os fundamentos do regime jurídico do "condomínio em edificações" da Lei de Condomínios em Edificações e Incorporações Imobiliárias.

24 “Art. 8․ Quando, em terreno onde não houver edificação, o proprietário, o promitente comprador, o cessionário deste ou o promitente cessionário sobre ele desejar erigir mais de uma edificação, observarse-á também o seguinte:

a) em relação às unidades autônomas que se constituírem em casas térreas ou assobradadas, será discriminada a parte do terreno ocupada pela edificação e também aquela eventualmente reservada como de utilização exclusiva dessas casas, como jardim e quintal, bem assim a fração ideal do todo do terreno e de partes comuns, que corresponderá às unidades;

b) em relação às unidades autônomas que constituírem edifícios de dois ou mais pavimentos, será discriminada a parte do terreno ocupada pela edificação, aquela que eventualmente for reservada como de utilização exclusiva, correspondente às unidades do edifício, e ainda a fração ideal do todo do terreno e de partes comuns, que corresponderá a cada uma das unidades;

c) serão discriminadas as partes do total do terreno que poderão ser utilizadas em comum pelos titulares de direito sobre os vários tipos de unidades autônomas;

d) serão discriminadas as áreas que se constituírem em passagem comum para as vias públicas ou para as unidades entre si."

25 Para maiores esclarecimentos, cf. PEREIRA, C. M. da S. Condomínio e Incorporações, 11. ed. atualizada por Sylvio Capanema de Souza e Melhim Namen Chalhub. Rio de Janeiro: Forense, 2003, p. 44-45.
} 
Sem embargo, JosÉ AfOnSO dA SILva adverte que o condomínio em conjuntos de edificações:

Tem sido usado abusivamente para fundamentar os tais 'loteamentos fechados'. Foi ele estabelecido [...] para possibilitar o aproveitamento de áreas de dimensão reduzida no interior de quadras, que, sem arruamento, permitam a construção de conjuntos de edificações, em forma de vilas, sob o regime condominial. Em situação como essa, a relação condominial é de grande utilidade, como na chamada propriedade horizontal. Quando, no entanto, a situação extrapola desses limites, para atingir o parcelamento de gleba com verdadeiro arruamento e posterior divisão das quadras em lotes, ou mesmo quando se trata apenas de subdivisão de quadra inteira em lotes, com aproveitamento das vias de circulação oficial preexistentes, então, aquele dispositivo não pode mais constituir fundamento do aproveitamento espacial, em forma de condomínio, porque aí temos formas de parcelamento urbanístico do solo, que há de reger-se pelas leis federais sobre loteamento e pelas leis municipais sobre a matéria urbanística, aplicáveis a esse tipo de urbanificação. ${ }^{26}$

Por cuidar de uma matéria precipuamente de direito privado, a Lei de Condomínios em Edificações e Incorporações Imobiliárias, assim como o atual Código Civil, não se preocupou em distinguir a natureza jurídica dos terrenos onde se fazem as incorporações imobiliárias, se são glebas ou lotes. Não é da preocupação do Direito Civil, mas do Direito Urbanístico, planejar, gerir e disciplinar o uso, ocupação e transformação do solo para fins urbanísticos, razão pela qual aquele diploma legal emprega o termo genérico "terreno" ao se referir ao imóvel a ser incorporado. O Direito Civil, portanto, posiciona-se à jusante dessa discussão, é dizer, além da perspectiva do condomínio para com o restante da cidade. Ele se ocupa tão somente em regular as relações privadas (internas) entre os proprietários do bem em discussão.

A suposta base legal de direito público para tal prática seria o art. 3ำ do Decreto-Lei 271/1967, cujo caput determina a aplicação da Lei Federal no 4.591/1964 aos loteamentos, "equiparando-se o loteador ao incorporador, os compradores de lote aos condôminos e as obras de infraestrutura à construção da edificação." 27 Essa tese ficou reforçada pela aprovação do Enunciado no 89 do Conselho da Justiça Federal na I Jornada de Direito Civil, nos dias 12 e 13 de setembro de 2002, nos termos do qual "[o] disposto nos arts. 1.331 a 1.358 do novo Código Civil aplica-se, no que couber, aos condomínios assemelhados, tais como loteamentos fechados, multipropriedade imobiliária e clubes de campo".

\footnotetext{
${ }^{26}$ Direito Urbanístico Brasileiro, 7. ed. São Paulo: Malheiros, 2012, p. 347.

27 Sem embargo, o $§ 1$ 음 do art. 3으 fixou prazo de 180 dias para que o Poder Executivo regulamentasse o Decreto-Lei no 271/1967, especialmente quanto à aplicação da Lei Caio Mário aos loteamentos, com as adaptações que se fizessem necessárias, o que jamais foi feito.
} 
Isso foi o campo fértil encontrado pelo mercado imobiliário para legitimar o "loteamento" do solo urbano sem cumprir os ônus urbanísticos exigidos na Lei de Parcelamento do Solo Urbano, designadamente a destinação de áreas para o arruamento público e a implantação de equipamentos públicos e espaços livres de uso público (art. 4o, inc. I), o que se convencionou denominar de condomínio urbanístico. Essa forma de transformação do solo urbano não é senão uma porta aberta à incorporação imobiliária em glebas, que são os terrenos inaptos à edificação, por não atenderem aos requisitos legais para que possam ser qualificados como lotes, quais sejam a existência de infraestrutura básica e dimensões condizentes com os índices urbanísticos definidos pelo plano diretor ou lei municipal para a zona em que se situem. ${ }^{28-29}$

Sendo a política de desenvolvimento urbano uma função pública a ser executada pelo Poder Público municipal, normas de direito privado regendo o parcelamento do solo urbano são incompatíveis com o objetivo da política de desenvolvimento urbano definido pela Carta Magna, qual seja "ordenar o pleno desenvolvimento das funções sociais da cidade e garantir o bem-estar de seus habitantes" (art. 182, caput). Prova eloquente disso é que a Lei de Condomínios em Edificações e Incorporações Imobiliárias, e também o Código Civil de 2002, ao tratar da circulação interna dos condomínios, apenas impõe que cada unidade autônoma tenha saída, direta ou por passagem comum, para a via pública (art. 2º, caput) e que a convenção de condomínio discrimine as passagens comuns para as vias públicas e para as unidades entre si (art. 8o, alínea ' $d$ '). ${ }^{30}$ Não existe qualquer preocupação de que as vias internas do condomínio articulem-se com as vias adjacentes oficiais, existentes ou projetadas, e harmonizem-se com a topografia local, que é requisito urbanístico mínimo para loteamentos (art. 4o, inc. IV, da Lei Federal no 6.766/1979).

\footnotetext{
${ }^{28}$ Lei de Condomínios em Edificações e Incorporações Imobiliárias: “Art. 28. [...] Parágrafo único. Para efeito desta Lei, considera-se incorporação imobiliária a atividade exercida com o intuito de promover e realizar a construção, para alienação total ou parcial, de edificações ou conjunto de edificações compostas de unidades autônomas, (VETADO)" - grifos nossos.

${ }^{29}$ Lei do Parcelamento do Solo Urbano: "Art. 2o. [...] § 40 Considera-se lote o terreno servido de infraestrutura básica cujas dimensões atendam aos índices urbanísticos definidos pelo plano diretor ou lei municipal para a zona em que se situe. (Incluído pela Lei no 9.785, de 1999)

§ 50 A infraestrutura básica dos parcelamentos é constituída pelos equipamentos urbanos de escoamento das águas pluviais, iluminação pública, esgotamento sanitário, abastecimento de água potável, energia elétrica pública e domiciliar e vias de circulação" (Incluído pela Lei no 9.785, de 1999) grifos nossos.

30 Da mesma forma, o Código Civil apenas determina que "[n]enhuma unidade imobiliária pode ser privada do acesso ao logradouro público" (art. 1.331, §4ㅇ).
} 
Em dezembro de 2007, comissão especial da Câmara dos Deputados destinada a proferir parecer sobre o Projeto de Lei Federal no 3.057/2000, em tramitação naquela Casa, aprovou um substitutivo que reformula completamente a Lei do Parcelamento do Solo Urbano e, entre outras mudanças, introduz o condomínio urbanístico como, simultaneamente, um tertium genus de parcelamento do solo urbano e uma nova modalidade de condomínio edilício, desvinculada da obrigação de incorporação imobiliária, senão vejamos:

Art. 2o. [...] XII - condomínio urbanístico: a divisão de imóvel em unidades autônomas destinadas à edificação, às quais correspondem frações ideais das áreas de uso comum dos condôminos, admitida a abertura de vias de domínio privado e vedada a de logradouros públicos internamente ao seu perímetro. [...]

Art. 4․ O parcelamento do solo para fins urbanos somente pode ser feito nas modalidades de loteamento, desmembramento ou condomínio urbanístico. [...]

Art. 123. As relações entre os condôminos do condomínio urbanístico regular-se-ão pelas disposições da Lei no 4.591, de 16 de dezembro de 1964, e pelo Código Civil Brasileiro.

Similarmente aos requisitos urbanísticos para loteamento previstos no atual art. $4 \stackrel{0}{\circ}, \S$ 1으, da Lei Federal no 6.766/1979, o art. 11, caput, do substitutivo remete "ao plano diretor ou a outra lei municipal definir, para as diferentes zonas em que se divide a área urbana do município":

I. os usos e os parâmetros urbanísticos de parcelamento e ocupação do solo;

II. as modalidades de parcelamento admissíveis;

III. as diretrizes para a articulação do parcelamento do solo com o desenho urbano;

IV. as diretrizes para o sistema de áreas verdes e institucionais.

Porém, o grande mérito do substitutivo fica por conta dos requisitos urbanísticos específicos para a implantação de condomínios urbanísticos, que, segundo $\circ \S 1$, "cabe à legislação municipal determinar":

I. os locais da área urbana onde essa implantação é admitida, respeitadas, se houver, as restrições estabelecidas pelo Plano Diretor;

II. a dimensão máxima do empreendimento ou do conjunto de empreendimentos contíguos;

III. os parâmetros relativos à contiguidade entre empreendimentos;

IV. as formas admissíveis de fechamento do perímetro;

V. a necessidade ou não de Estudo Prévio de Impacto de Vizinhança (EIV);

VI. os critérios e as responsabilidades em relação à manutenção da infraestrutura básica e da complementar;

VII. os casos e as condições em que é exigida reserva de áreas destinadas a uso público; 
VIII. outros requisitos julgados necessários para assegurar a mobilidade urbana e o livre acesso às praias e demais bens de uso comum do povo.

E, na ausência da aludida legislação municipal, o § 2o veda a outorga de licença para a implantação de condomínios urbanísticos. ${ }^{31}$

Em linhas gerais, algumas de nossas reservas aos loteamentos fechados e, em menor medida, aos loteamentos de acesso controlado, nomeadamente a possibilidade de frustração do direito à mobilidade urbana eficiente (art. 144, § 10, inc. I, da CRFB) e a desconsideração das funções sociais da cidade (art. 182, caput, da CRFB), são extensíveis aos condomínios urbanísticos. Estes têm uma tendência natural a "feudalizar" a cidade, gerando largos extratos de territórios sem coesão com o que jaz a seu redor, e dificultando a presença do Poder Público e de seus serviços. Contudo, em nosso entender, o condomínio urbanístico previsto nesse projeto de lei federal não é forçosamente inconstitucional; antes, o projeto desloca a discussão de constitucionalidade para o nível local, já que será o plano diretor ou a legislação municipal dele decorrente que assentará os requisitos urbanísticos para a implantação dos condomínios urbanísticos. A constitucionalidade do condomínio urbanístico dependerá, pois, da validade constitucional dos requisitos que o plano diretor ou a legislação municipal dele derivada definir, isto é, se as opções adotadas pelo legislador da comuna baldarão ou não o direito à mobilidade urbana eficiente e as funções sociais da cidade. Seja como for, não há como se negar que o substitutivo proposto, se comparado à Lei Caio Mário, representará um grande avanço em termos de ordenamento urbanístico.

Já o condomínio de lotes, instituído pela Lei Federal № 13.465/2017, foi inspirado no Projeto de Lei do Senado (PLS) no 208/2015, ainda em tramitação na Casa, de autoria do então Sen. Marcelo Crivella. Diferentemente do condomínio urbanístico, não se trata aqui de nova espécie de parcelamento do solo urbano, mas de um tipo de condomínio edilício com unidades autônomas constituídas diretamente sobre partes de terreno, e não sobre edificações ou partes de edificações, como resultado de um loteamento ou desmembramento. A inclusão do $\S 7$ no no art. 2으 da Lei Federal no 6.766/1979, que é essencialmente idêntica ao acréscimo proposto para o mesmo artigo pelo PLS no 208/2015, com a diferença de que este fala em "condomínio

\footnotetext{
${ }^{31}$ Disponivel em: http://www.camara.leg.br/internet/ordemdodia/integras/535225.htm. Acesso em: 12 jun. 2017.
} 
edilício" e aquela em "condomínio de lotes", não dá margem a outra interpretação. ${ }^{32}$ Isso fica confirmado pelo Parecer (CN) no 1/2017, a saber:

Por meio do condomínio de lotes, permite-se que as quadras privadas derivadas do parcelamento do solo sejam organizadas sob a forma de condomínio, independentemente de edificação. Tal sistema não é uma alternativa ao loteamento tradicional, pois em nada altera os ônus a que se encontra submetido o empreendedor. Além disso, assegura-se à prefeitura a prerrogativa de instituir servidões de passagem em benefício dos não moradores e de disciplinar a construção de muros e cercas, com vistas à proteção da paisagem. ${ }^{33}$

Disso decorre que a constituição do condomínio de lotes ocorre no momento do registro do projeto de loteamento ou desmembramento aprovado pela prefeitura municipal, ou pelo Governo do Distrito Federal, quando for o caso. Todavia, a despeito do silêncio da lei, entendemos possível a conversão de lotes constituídos sob a forma de imóvel autônomo em unidades imobiliárias integrantes de condomínio de lotes após o registro do projeto de loteamento ou desmembramento. Essa faculdade deverá ser exercitada por analogia ao regime jurídico do desdobro, se o condomínio for formado a partir da conversão de um único lote, ou do remembramento, se o condomínio for formado a partir da fusão de dois ou mais lotes contíguos da mesma quadra. ${ }^{34}$

O § 4으 do art. 4ㅇ da Lei Federal ํo 6.766/1979, também incluído pela Lei Federal № 13.465/2017, que faculta a instituição de "limitações administrativas e direitos reais sobre coisa alheia em prol do Poder Público, da população em geral e da proteção da paisagem urbana", é substancialmente igual à inserção proposta pelo PLS no 208/2015. ${ }^{35}$

\footnotetext{
32 Lei Federal no 6.766/1979: “Art. 2o. [...] § 70 O lote poderá ser constituído sob a forma de imóvel autônomo ou de unidade imobiliária integrante de condomínio de lotes. (Incluído pela Lei no 13.465, de 2017)"

PLS no 208/2015: “Art. 2ㅇ. [...] § 70 O lote poderá ser constituído sob a forma de imóvel autônomo ou de unidade imobiliária integrante de condomínio edilício."

33 Disponivel em: https://legis.senado.leg.br/sdleg-getter/documento?dm=5280347\&disposition=inline. Acesso em: 21 ago. 2017.

${ }^{34}$ CARVAlHo PINTO esclarece que, "[e]mbora não constem da lei federal, a doutrina e a legislação municipal têm adotado, ainda, os conceitos de desdobro e de remembramento. O primeiro seria a subdivisão de um lote em dois ou mais lotes menores, enquanto o segundo seria a fusão de dois ou mais lotes em um lote maior" (grifos do original), cf. O reparcelamento do solo: um modelo consorciado de renovação urbana. In: Textos para Discussão, n. 130. Brasília: Núcleo de Estudos e Pesquisas do Senado, 2013, p. 28. 35 Lei Federal no 6.766/1979: “Art. 4ㅇ. [...] § 4ㅇ№ caso de lotes integrantes de condomínio de lotes, poderão ser instituídas limitações administrativas e direitos reais sobre coisa alheia em benefício do poder público, da população em geral e da proteção da paisagem urbana, tais como servidões de passagem, usufrutos e restrições à construção de muros. (Incluído pela Lei no 13.465, de 2017)"

PLS no 208/2015: “Art. 4ㅇ. [...] § 4ㅇ No caso de lotes integrantes de condomínio edilício, poderão ser exigidas servidões de passagem em benefício da população em geral e fixadas normas sobre a construção de muros e cercas voltadas para a proteção da paisagem urbana."
} 
A Lei Federal no 13.465/2017 também precisou adaptar o Código Civil para possibilitar a constituição de condomínios edilícios com unidades autônomas na forma de lotes. Contudo, no lugar de modificar o caput e o $\S 1$ 으 do art. 1.331 do Código Civil, conforme propõe o PLS no 208/2015, ela adicionou uma dispensável Seção IV no Capítulo “Do Condomínio Edilício" do Código Civil, com um artigo único (art. 1.358-A), cujos parágrafos são redundantes e de técnica legislativa ainda pior do que a do caput. ${ }^{36} \mathrm{O} \S 1$ 임 do art. 1.358-A já é contemplado pelo art. 1.331, § 3ำ, do Código Civil, na redação dada pela Lei Federal no 10.931, de 02 de agosto de 2004, que deixa o critério de definição da fração ideal para o instrumento de instituição do condomínio (leia-se convenção), uma vez que o condomínio de lotes não é senão um caso particular de condomínio edilício. ${ }^{37} \mathrm{O} \S 2$ 으 do art. 1.358-A poderia ser dispensado por motivo de economia legislativa, já que o condomínio de lotes é um caso particular de condomínio edilício. E o § 3ㅇ do art. 1.358-A é evidente, em razão de o art. 18, inc. V, da Lei Federal no 6.766/1979 já colocar a cargo do empreendedor a implantação da infraestrutura no lote, além de que o art. 1.331, § 2으, do Código Civil considera a infraestrutura como propriedade comum dos condôminos, inalienável separadamente e indivisível. ${ }^{38}$

\footnotetext{
${ }^{36}$ Código Civil: "Art. 1.358-A. Pode haver, em terrenos, partes designadas de lotes que são propriedade exclusiva e partes que são propriedade comum dos condôminos. (Incluído pela Lei no 13.465 , de 2017) $\S 1$ 10 A fração ideal de cada condômino poderá ser proporcional à área do solo de cada unidade autônoma, ao respectivo potencial construtivo ou a outros critérios indicados no ato de instituição. (Incluído pela Lei no 13.465, de 2017)

$\S 2$ - Aplica-se, no que couber, ao condomínio de lotes o disposto sobre condomínio edilício neste Capítulo, respeitada a legislação urbanística. (Incluído pela Lei no 13.465, de 2017)

$\S 3$ o Para fins de incorporação imobiliária, a implantação de toda a infraestrutura ficará a cargo do empreendedor. (Incluído pela Lei no 13.465 , de 2017)"

PLS no 208/2015: “Art. 1.331. Pode haver, em imóveis, partes que são propriedade exclusiva e partes que são propriedade comum dos condôminos.

$\S 1$ 을 As partes suscetíveis de utilização independente, tais como lotes, apartamentos, escritórios, salas, lojas e sobrelojas, com as respectivas frações ideais no solo e nas outras partes comuns, sujeitam-se a propriedade exclusiva, podendo ser alienadas e gravadas livremente por seus proprietários, exceto os abrigos para veículos, que não poderão ser alienados ou alugados a pessoas estranhas ao condomínio, salvo autorização expressa na convenção de condomínio. (NR)"

${ }^{37}$ Código Civil: "Art. 1.331 § 3o A cada unidade imobiliária caberá, como parte inseparável, uma fração ideal no solo e nas outras partes comuns, que será identificada em forma decimal ou ordinária no instrumento de instituição do condomínio. (Redação dada pela Lei no 10.931, de 2004)"

${ }^{38}$ Lei Federal no 6.766/1979: "Art. 18. Aprovado o projeto de loteamento ou de desmembramento, o loteador deverá submetê-lo ao registro imobiliário dentro de 180 (cento e oitenta) dias, sob pena de caducidade da aprovação, acompanhado dos seguintes documentos:

[...] $\vee$ - cópia do ato de aprovação do loteamento e comprovante do termo de verificação pela Prefeitura Municipal ou pelo Distrito Federal, da execução das obras exigidas por legislação municipal, que incluirão, no mínimo, a execução das vias de circulação do loteamento, demarcação dos lotes, quadras e logradouros e das obras de escoamento das águas pluviais ou da aprovação de um cronograma, com a duração máxima de quatro anos, acompanhado de competente instrumento de garantia para a execução das obras; (Redação dada pela Lei no 9.785, de 1999)"
} 
A justificativa do PLS no 208/2015 e, por extensão, a do condomínio de lotes da Lei Federal no 13.465/2017 são duas: (I) eliminar a insegurança jurídica gerada, de um lado, pela falta de amparo na legislação civil para a constituição de condomínios edilícios sem edificações e, do outro lado, pela omissão da Lei Federal no 6.766/1979 quanto à possibilidade de subdivisão de glebas sob a forma condominial, como alternativa ao parcelamento do solo tradicional; e (II) coibir os abusos de legislações municipais contra as lacunas da legislação federal vigente, assim garantindo o cumprimento dos ônus urbanísticos nas operações de parcelamento do solo. ${ }^{39}$ Sem embargo, a faculdade de o lote constituir unidade imobiliária integrante de condomínio edilício, de propriedade exclusiva, como resultado de um loteamento ou desmembramento, acarreta dois problemas: um de ordem teleológica e outro de ordem conceitual.

Teleologicamente, se a finalidade é eliminar a insegurança jurídica existente e garantir o cumprimento dos ônus urbanísticos em parcelamentos do solo urbano, tanto um quanto a outra fracassam. Ao admitirem a constituição de condomínios edilícios com unidades autônomas instituídas sobre lotes, e não apenas sobre edificações ou partes de edificações, afasta-se o óbice da competência privativa da União para dispor sobre normas de Direito Civil (art. 22, inc. I, da CRFB), encontrando os municípios caminho livre para estabelecerem categorias híbridas de parcelamento do solo urbano, tais como o condomínio urbanístico. Isso porque o Poder Público local não afronta o esquema de repartição de competências constitucionais ao estabelecer formas especiais de parcelamento do solo para além daquelas contempladas pela lei federal, sobretudo porque o art. ㄴo da Lei Federal ํo 6.766/1979 não diz que o parcelamento do solo "somente" poderá ser feito mediante loteamento ou desmembramento. ${ }^{40}$ Importa ter presente que o art. 30, inc. II, da CRFB atribui aos municípios

Código Civil: "Art. 1.331. [...] § 2o O solo, a estrutura do prédio, o telhado, a rede geral de distribuição de água, esgoto, gás e eletricidade, a calefação e refrigeração centrais, e as demais partes comuns, inclusive o acesso ao logradouro público, são utilizados em comum pelos condôminos, não podendo ser alienados separadamente, ou divididos."

39 Disponível em: https://legis.senado.leg.br/sdleg-getter/documento?dm=584171\&disposition=inline. Acesso em: 21 ago. 2017.

40 Analogamente a nossa tese, a Segunda Câmara Cível do Tribunal de Justiça de Minas Gerais entendeu que, em não se tratando da hipótese de constituição de loteamento ou desmembramento de solo, mas de desdobro de imóvel já registrado, é inaplicável a norma contida no art. 4으, inc. II, da Lei Federal no 6766/1979, que fixa o módulo urbano em $125 \mathrm{~m}^{2}$ (cento e vinte cinco metros quadrados) e a testada mínima do lote em 5 m (cinco metros), cf. TJMG. Apelação Cível no 1.0016.13.004163-1/001 (Segunda Câmara Cível). In: Diário do Judiciário Eletrônico, 24 fev. 2014. Rel. Des. Hilda Teixeira da Costa. Em sentido oposto, defendendo que, mesmo a Lei do Parcelamento do Solo Urbano não incidindo sobre os desdobros, essa forma de parcelamento do solo não pode desobedecer ao comando do art. 3o, parágrafo 
competência para suplementar a legislação federal e a estadual no que couber, neste particular de Direito Urbanístico. Na ausência de normas gerais, federais e estaduais, em sede de competência concorrente, o município afetado pela inércia da União e do respectivo estado tem competência implícita para legislar plenamente sobre assuntos de seu interesse local (art. 30, inc. I), com amparo no princípio federativo (art. 18, caput) e no princípio da autonomia municipal (art. 29, caput, e art. 34, inc. VII, alínea ' $c$ '). ${ }^{41}$ O simples fato de existir lei federal sobre normas gerais não obsta o exercício dessa competência legislativa plena para preencher lacunas deixadas pela União, sendo válida a analogia com o art. 24, §§ 3o e 4으, da CRFB. ${ }^{42}$ Consequentemente, o condomínio de lotes não só não resolve o problema da burla aos encargos urbanísticos impostos pela Lei de Parcelamento do Solo Urbano, como facilita a elaboração de legislações locais com potencial de lesividade ao interesse público.

Conceitualmente, os terrenos onde se instalam os condomínios de lotes não são glebas, porque os lotes constituídos a partir de sua subdivisão, sob a forma de unidades imobiliárias integrantes de condomínio de lotes, perderiam a destinação edificatória, anulando-se a própria finalidade do parcelamento do solo, que é garantir a possibilidade de construir no solo. Tampouco são lotes, porque estes são as partes de terrenos sujeitas a propriedade exclusiva, não se confundindo com o todo do condomínio, que também tem partes de propriedade comum. Logo, não sendo glebas nem lotes, esses terrenos só podem revestir natureza jurídica de quadras, ou de subquadras, consoante o projeto de parcelamento apresentado à Administração Pública local, nos termos do art. 9o da Lei Federal no 6.766/1979. ${ }^{43}$ Portanto,

único, e art. 4으, inc. II, ambos da Lei Federal no 6.766/1979, cf. MUKAl, T. Direito Urbano e Ambiental, 4. ed. Belo Horizonte: Fórum, 2010, p. 144; 157.

${ }^{41}$ DI SARNO, D. C. L. Competências urbanísticas. In: DALLARI, Adilson de Abreu; FERRAZ, Sérgio (coord.). Estatuto da Cidade: Comentários à Lei Federal 10.257/2001, 4. ed. São Paulo: Malheiros, 2014, p. 67.

42 “Art. 24. [...] § 3ㅇ Inexistindo lei federal sobre normas gerais, os Estados exercerão a competência legislativa plena, para atender a suas peculiaridades.

§ 4으 A superveniência de lei federal sobre normas gerais suspende a eficácia da lei estadual, no que lhe for contrário."

43 "Art. 9o Orientado pelo traçado e diretrizes oficiais, quando houver, o projeto, contendo desenhos, memorial descritivo e cronograma de execução das obras com duração máxima de quatro anos, será apresentado à Prefeitura Municipal, ou ao Distrito Federal, quando for o caso, acompanhado de certidão atualizada da matrícula da gleba, expedida pelo Cartório de Registro de Imóveis competente, de certidão negativa de tributos municipais e do competente instrumento de garantia, ressalvado o disposto no $\S$ 4ㅇdo art. 18. (Redação dada pela Lei no 9.785, de 1999)

$\S 1$ 으 - Os desenhos conterão pelo menos:

I - a subdivisão das quadras em lotes, com as respectivas dimensões e numeração;

II - o sistema de vias com a respectiva hierarquia;

III - as dimensões lineares e angulares do projeto, com raios, cordas, arcos, pontos de tangência e ângulos centrais das vias; 
convinha que a legislação federal definisse essas duas categorias jurídicas e elucidasse, entre outros aspectos, se se trata de terrenos destinados a edificação ou não. ${ }^{44}$ Assim, não Ihes reconhecendo a lei vocação edificatória, à semelhança das glebas, as partes comuns dos condomínios de lotes prestar-se-iam basicamente a vias de circulação interna e espaços livres. Do contrário, reconhecendo-Ihes a lei aptidão para edificação, à semelhança dos lotes, é suposto que os condôminos possam levantar edificações (v.g., salões de festas, ginásios multidesportivos, mercados, escolas particulares, centros comerciais etc.) sobre as partes comuns do condomínio para atender sua demanda interna, gerando economia de escala.

\section{CONCLUSÃO}

A Lei Federal no 13.465/2017 promoveu uma reviravolta na legislação urbanística federal, neste particular o parcelamento do solo urbano, positivando, entre outras figuras jurídicas, o loteamento de acesso controlado e o condomínio de lotes.

O loteamento de acesso controlado (arts. 2ํ, § 8o, e 36-A da Lei Federal oㅡ 6.766/1979) é uma modalidade de loteamento cujo acesso a suas vias de circulação é controlado, com base em regulamento municipal, mediante identificação ou cadastro, após o qual é vedado impedir o ingresso de não residentes, sejam eles pedestres ou condutores de veículos. Diversamente do

IV - os perfis longitudinais e transversais de todas as vias de circulação e praças;

$\checkmark-a$ indicação dos marcos de alinhamento e nivelamento localizados nos ângulos de curvas e vias projetadas;

$\mathrm{VI}$ - a indicação em planta e perfis de todas as linhas de escoamento das águas pluviais.

§ 2o- O memorial descritivo deverá conter, obrigatoriamente, pelo menos:

I - a descrição sucinta do loteamento, com as suas características e a fixação da zona ou zonas de uso predominante;

II - as condições urbanísticas do loteamento e as limitações que incidem sobre os lotes e suas construções, além daquelas constantes das diretrizes fixadas;

III - a indicação das áreas públicas que passarão ao domínio do município no ato de registro do loteamento;

IV - a enumeração dos equipamentos urbanos, comunitários e dos serviços públicos ou de utilidade pública, já existentes no loteamento e adjacências.

$\S 3$ - Caso se constate, a qualquer tempo, que a certidão da matrícula apresentada como atual não tem mais correspondência com os registros e averbações cartorárias do tempo da sua apresentação, além das consequências penais cabíveis, serão consideradas insubsistentes tanto as diretrizes expedidas anteriormente, quanto as aprovações consequentes. (Incluído pela Lei no 9.785, de 1999)"

${ }^{44}$ A título de referência, o Quadro 1 do Anexo da Lei de Parcelamento, Uso e Ocupação do Solo do Município de São Paulo (Lei Municipal no 16.402, de 22 de março de 2016) define quadra como a "área resultante de loteamento, delimitada por vias oficiais de circulação ou demais logradouros públicos". Já o art. 10, inc. XX, da Lei de Parcelamento do Solo Urbano do Município do Recife (Lei Municipal no 16.286, 22 de janeiro de 1997) define subquadra como o "conjunto de terrenos em parte de uma quadra, também ocupada por lotes da propriedade contígua". Nada obstante, como se constata, nenhum dos dois diplomas legais enfrenta a questão da edificabilidade desses terrenos. 
loteamento fechado, situação jurídica que - além de inconstitucional - doravante passa a ser uma situação estritamente ilegal, o loteamento de acesso controlado não ofende, em sua relação interna, o princípio da legalidade (art. 50, inc. II, da CRFB) e, em sua relação externa, a liberdade de locomoção (art. 5ㅇ, inc. XV, da CRFB), o direito à mobilidade urbana eficiente (art. 144, § 10, inc. I, da CRFB) e as funções sociais da cidade (art. 182, caput, da CRFB). Não obstante, essa nova modalidade de loteamento é claramente inconstitucional por violar a liberdade de associação (art. 5, inc. XX) dos residentes do loteamento que não desejem associar-se ou permanecer associados. Além disso, o loteamento de acesso controlado atenta contra o princípio da igualdade (art. 5ํ, caput) e contra os direitos à intimidade e à vida privada (art. 5o, inc. X), na medida em que constrange não residentes do loteamento - e só esses - a se identificarem perante terceiros para adentrarem os respectivos logradouros públicos.

O condomínio de lotes (arts. 2o, § 7으, e 4으, § 4으, da Lei Federal ํo 6.766/1979 e art. 1.358-A do Código Civil) é um tipo de condomínio edilício com unidades autônomas constituídas diretamente sobre partes de terreno, e não sobre edificações ou partes de edificações, como resultado de um parcelamento do solo urbano. Não se confunde com o condomínio urbanístico, porque este é uma espécie de parcelamento do solo, diversa do loteamento e do desmembramento, que não destina áreas para implantação de equipamentos públicos e nem reserva espaço para espaços livres de uso público. Muito pelo contrário, o condomínio de lotes foi inspirado no PLS no 208/2015, ainda em tramitação no Senado Federal, que visa a eliminar a insegurança jurídica causada pela omissão legal relativa ao parcelamento do solo urbano sob a forma de condomínio edilício, e a coibir os abusos baseados em legislações municipais colmatadoras, que possibilitam ao mercado imobiliário furtar-se ao cumprimento dos ônus urbanísticos do parcelamento do solo urbano tradicional. Por não se apresentar como uma alternativa ao loteamento ou ao desmembramento, e sim como uma forma diversa de aproveitamento particular de quadras ou subquadras geradas pelo parcelamento do solo, o condomínio de lotes não levanta grandes preocupações de natureza constitucional. No entanto, ao admitir a constituição de condomínios edilícios com unidades autônomas instituídas sobre lotes, e não apenas sobre edificações ou partes de edificações, a Lei Federal no 13.465/2017 carrega um problema de ordem teleológica: não apenas não evita a burla aos encargos urbanísticos da Lei de Parcelamento do Solo Urbano, como também elimina os entraves constitucionais para que o legislador municipal aprove espécies de parcelamento do solo nocivas ao interesse público. E também, ao não definir expressamente que os imóveis onde são constituídos os condomínios de lotes são quadras, ou subquadras, conforme o caso, a Lei 
Federal no 13.465/2017 esbarra num problema de ordem conceitual, já que não é possível assegurar se se trata de terrenos com vocação edificatória ou não.

\section{REFERÊNCIAS BIBLIOGRÁFICAS}

CARVALHO FILHO, José dos Santos. Manual de Direito Administrativo. Rio de Janeiro: Lumen Juris, 2007.

CORREIA, Fernando Alves. Manual de Direito do Urbanismo, vol. I, 4. ed. Coimbra: Almedina, 2008.

DI SARNO, Daniela Campos Libório. Competências urbanísticas. In.: DALLARI, Adilson de Abreu; FERRAZ, Sérgio (coord.). Estatuto da Cidade: Comentários à Lei Federal 10.257/2001, 4. ed. São Paulo: Malheiros, 2014, p. 63-73.

FEDOZZI, Marcos Eduardo Goiana. Condomínio edilício no Novo Código Civil. Rio de Janeiro: Forense, 2007.

KOJRANSKI, Nelson. Condomínio edilício: aspectos jurídicos relevantes, 2. ed. São Paulo: Malheiros, 2015.

LE CORBUSIER. A Carta de Atenas, trad. Rebeca Scherer. São Paulo: HUCITEC: EDUSP, 1993.

MEIRELLES, Hely Lopes. Direito administrativo brasileiro, 16. ed. atualizada pela Constituição de 1988. São Paulo: RT, 1991.

Direito municipal brasileiro, 17. ed. atualizada por Adilson Abreu Dallari (coord.). São Paulo: Malheiros, 2014.

MUKAI, Toshio. Impossibilidade jurídica da desafetação legal de bens de uso comum do povo, na ausência de desafetação de fato. In: Revista de Direito Público, n. 75. São Paulo: RT, 1985, p. 246-249.

Direito Urbano e Ambiental, 4. ed. Belo Horizonte: Fórum, 2010.

PEREIRA, Caio Mário da Silva. Condomínio e Incorporações, 11. ed. atualizada por Sylvio Capanema de Souza e Melhim Namen Chalhub. Rio de Janeiro: Forense, 2014.

PINTO, Victor Carvalho. O reparcelamento do solo: um modelo consorciado de renovação urbana. Textos para Discussão, n. 130. Brasília: Núcleo de Estudos e Pesquisas do Senado, 2013.

SILVA, José Afonso da. Direito Urbanístico Brasileiro, 7. ed. São Paulo: Malheiros, 2012.

Trabalho enviado em 20 de outubro de 2017.

Aceito em 26 de outubro de 2017. 